\title{
Improving Beginning Reading Skill Through Mini Garden
}

\author{
Mia Rachmawaty \\ Faculty of Education \\ Universitas Trilogi \\ Jakarta, Indonesia \\ Mia_rachmawaty@trilogi.ac.id
}

\begin{abstract}
This action research is motivated by the lack of teacher's knowledge in the strategy of children's beginning reading skill. They use flash card without knowing and showing the symbol of code for children in steps. Children sometimes avoid and even refuse to join beginning reading activity. The purpose of this study is to improve the ability on children's beginning reading by using mini garden in a daycare that has a small space in their outdoor area. This study used action research with two variables: the beginning reading ability $(Y)$ and mini garden $(X)$. The results showed an increase for $50,4 \%$ and for the second cycle the result raised to $94,6 \%$. The second result showed the highest percentage up to $100 \%$ that was obtained by two children as the respondents and lowest percentage was $73 \%$ that was obtained by one of the respondent in total of 13 respondents.
\end{abstract}

\section{Keywords—beginning reading ability, mini garden}

\section{INTRODUCTION}

Reading involves mental activity that can ensure the acquisition of a person's ability to comprehend an object maximally because language development increases along with cognitive development. Children who have successfully learned to read in preschool will be more likely to learn other things at the elementary level and show good academic performance [1]. Reading is one of the adventures that stimulate the child emotionally to satisfy the child's curiosity about the environment. Reading is a process of encoding and reading a password (a recording and decoding process) [2]. The Decoding aspect is to incorporate written words or graphic into oral language meaning or letter prints into meaningful sounds. Recording aspect is aimed at the composition of words and sentences and then is associated with the sounds according to the writing system used.

The foundations of reading development are oral language proficiency and print language [3]. At the age of 3, the child's vocabulary increases very rapidly and the ability to explore with the surrounding environment is also increasingly visible. Children interact with the environment involving the ability of oral and visual to explore the writings and prints that exist around them. Reading is an individual development process derived from the natural ability (nurture) and learned through practice activities and daily literacy exercises. The three components of literacy associated with early reading skills are printed knowledge, spoken language skills, and phonological awareness [4]. Prints can be easily found in the daily life of children, at school or in daycare. Ana Isabel Pinto explained that the quality of childcare is positively associated with children's language, communication and early literacy skill during preschool [5]. The teacher may encourage their attention and curiosity of print into the reading activity. In a print, there are symbols that can lead to the beginning reading ability [6]. Through the visual ability, children can see many prints, writings and symbol images as a code. But firstly, they must be able to decode and encode them to understand the symbols and written text, then the child will be able to record or sound the symbol.

Print literacy can be supported in meaningful and playbased situations when preschool teacher have knowledge to support young children's interest in reading and writing [7]. Literacy environment is a learning environment for children to explore the visual learning experience of written symbols. Jo Ann Brewer states that early literacy programs are implemented in preschool by providing literacy environments in order to provide a strong foundation for the development of early reading skills for children [8]. Using signs and symbols in a child's learning environment can make it easier for children to understand the meaning and engage in the next stage of literacy learning [9]. Printed symbols also provide information for children about objects that contain pictures, posts, or stages of instruction. The literacy environment is built inside or outside the classroom. Holly Farrel stated that the mini garden is a small park that provides rewards not only for those who have limited space, but also who have limited time [10]. At the school, Mini garden is a small space of land from the outdoor area of the school that is used to plant a productive plant for students and teachers and is an alternative source of learning. Muge Yurtsever Kilicgun explains that school gardens are places where children meet their needs such as breathe fresh air, relaxation, learning, movement and playing. A wellplanned garden should be able to meet children's needs [11]. School garden has significant opportunities for educational and community-based sustainability project and teachers are the key actors in shaping schools' gardens. They are required to give particular attention to such idea to support their implementation into pedagogical practice [12]. For early childhood, Mini garden activities involve the motion of child motoric activity, exploring with visual activities, oral activities that enable interaction between the ecosystem environments with children who use learning tools in the mini garden. Tsuyoshi Okayama and Kazuya Miyawaki explain that there is 
a support system in "Smart Garden" in the form of visual information and contained the unique symbols [13]. Plant nametags and work information symbols from the gardening stages and garden equipment labels are made for children to know and understand the instructions in the mini garden. Ellen Almers, Per Askerlund, and Sofia Kjellstrom explained that mini garden is an art and handicraft activity to make the label from wood pieces to write the names of species and plants [14]. Therefore, in the mini garden, there are activities that support the process of the beginning reading with the presence of symbols and written signs printed and installed in the mini garden.

The daycare time can be allocated as mini garden because the number of study hours in daycare is longer, that is 8-12 hours per day compared with formal Kindergarten which is only 4-5 hours per day. In this study, Dandelion Daycare Plus has mini garden as a strategic activity to the beginning reading. Previously, researchers have observed children aged 5-6 years. They seem to have low interest in the beginning reading activity and have low early reading ability. This may be caused by the teachers who only do spelling the image card without pictures in activities that are less attractive to children. It leads children to sometimes refuse, even avoid following the reading activities. This is a problem that must be overcome. Inappropriate strategies lead to the ability of the lack of early reading skills in children.

The problems of this research are: (1) how does the mini garden improve the beginning reading ability of the children aged 5-6 years old in Dandelion Daycare Plus? (2) Can the mini garden activates improve the beginning reading ability of children aged 5-6 years old in Dandelion Daycare Plus?

\section{METHODS}

This research used action research method. This action was conducted in the spiral form of each cycle trough systematic steps that actively include study participants using the Kemmis and Taggart model. It includes four stages: (1) planning, (2) action, (3) observation, and (4) reflection [15], they are shown as in fig. 1 .

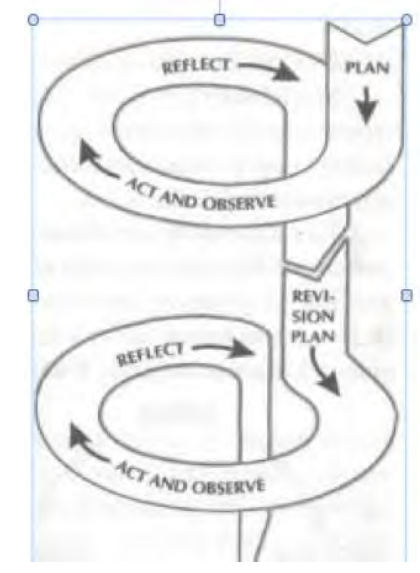

Fig. 1. Procedure/design of action research Kemmis and Taggart
The research design is mix method employing qualitative and quantitative method. Qualitative method aims to examine the learning process. Meanwhile, the qualitative method aims to examine the result of the ability on the children's beginning reading with mini garden activities.

The overall achievement targets increase the ability on the beginning reading, where it has been reached $73 \%$. This is seen based on the minimum completeness of the Dandelion daycare academic score by $73 \%$ as final result. Action research said if the child has increased the score of learning achievement at least $71 \%$, the children show their success. If the percentage obtained is less than $71 \%$ for learning score, then the research will be continued in the next cycle; cycle II.

\section{A. Action Research Procedures}

In the research procedure there were pre observation, planning, action, observation and reflection:

- Pre observation,

The activities undertaken at this pre observation are: (1) determining the place of study and the problem studied, (2) collecting information about the learning with the activities of mini garden and about the ability on beginning reading skill.

- Planning,

After the pre observation was done, the next step was to plan the activities to be implemented. They were: (1) determining the target of competence to be achieved, (2) designing the mini garden activities used for each action or meeting at each cycle, (3) determining the activity steps for each meeting/action, (4) setting the location of activities and preparing the tools, materials, media used.

- Action,

Implementations of the action were done eight times in cycle I. The result and level of success of child was shown at cycle I. If result and level of success had not reached the expected grade, then there would be cycle II.

- Observation,

Observations were made during the execution of action on mini garden activities with observation guidelines. The observation includes indicators that were designed based on the focus of the study and the concentration of numeracy learning to be improved. Observation covers sheets filling, and interview was also used as tool in the research. The camera was also used to record or document the process of action activity. It reveals how the child does mini garden activities.

- Reflection,

Reflection was done by analyzing the results of actions performed by the child. It reveals whether the action can increase or even a decrease children's ability on beginning reading skill. 


\section{B. Data Validation Technique}

Popham said that data validation as "the degree of which test score are free of error measurement". To know the reliability of research instruments, it was used Cronbach Alpha as shown in (1).

$$
\mathrm{ri}_{\mathrm{i}}=\frac{\mathrm{k}}{(\mathrm{k}-1)} \quad\left\{1-\frac{\Sigma_{\mathrm{s}_{i}}{ }^{2}}{\mathrm{~s}_{\mathrm{t}}{ }^{2}}\right\}
$$

$$
\begin{array}{ll}
\mathrm{r} 11 & : \text { Value of reliability } \\
\sum_{\mathrm{S}} \mathrm{S}_{\mathrm{i}} & : \text { Number of variants of score items } \\
\mathrm{S}_{\mathrm{t}} & : \text { Total variant } \\
\mathrm{K} & : \text { Total items }
\end{array}
$$

\section{Data Analysis Technique}

Data analysis was divided into two parts, the analysis of qualitative and quantitative data. Qualitative data was obtained from observations, interviews, documentation and reflection results that were collected and sorted by type, then analyzed inductively, with data reduction, data display and data verification. The quantitative data was taken from the assessment of the concentration development of comparative learning which was processed statistically to test the hypothesis of action. That was done in a means of using the study of the proportion of values

\section{RESUltS}

Observation from the actions was undertaken during the implementation. It is necessary in conducting data analysis in quantitative and qualitative terms. Observations were made using: observation instruments. The types of instruments used were field notes, documentation and interviews. The improvement of the beginning reading ability in children group of 5-6 years old at Dandelion Daycare Plus, Depok can be seen in the following graph:

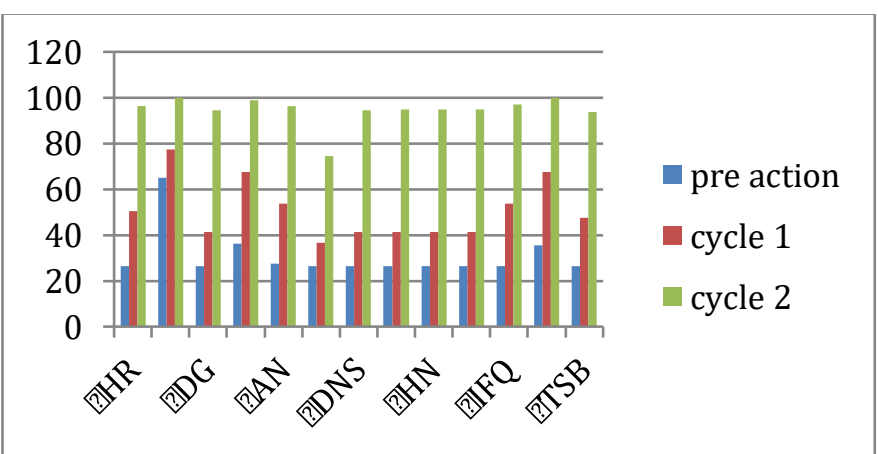

Fig. 2. Graph of Comparison of Pre-Action Score Result, Cycle I and Cycle II the Improvement of Beginning Reading Ability Through Mini Garden.

From the graph above, it can be concluded the beginning reading on children at 5-6 years old at Dandelion Daycare plus Depok has increased significantly and reached the number that has been targeted. The results showed an increase for overall percentage at pre cycle which was counted as many as $30.6 \%$. After measuring the first cycle, the result increased up to
$50.4 \%$, and for the second cycle it was raised up to $94.6 \%$. From the second result, the highest percentage was obtained. It was up to $100 \%$ that obtained by BT and AQF as the respondent while the lowest percentage was $73 \%$ that obtained by AGH as the respondent. This shows the effectiveness of the use of mini garden as an activity to improve the beginning reading.

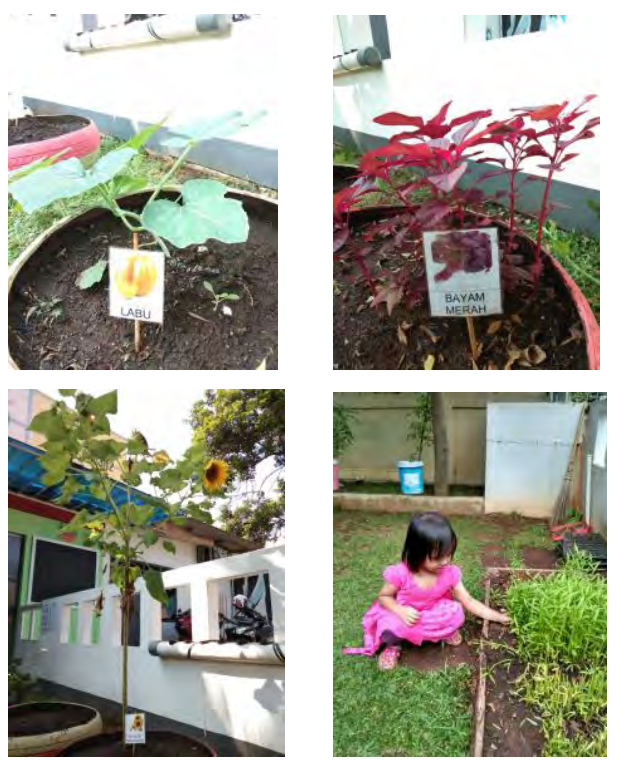

Fig. 3. Mini Garden Activity

\section{CONCLUSION}

- The result of the overall percentage of individual values in the pre-action, cycle I and cycle II have reached the total score of $73 \%$, while the average class has reached a total score of $94,6 \%$.

- Mini Garden is able to increase the beginning reading ability that can be seen from the improvement of development achievement concentration in reading symbols, signs and letter sounds at $30,6 \%$ in pre cycle or pre action and cycle I for $50,4 \%$ and $94,6 \%$ in cycle II.

- There is a significant increase of pre-action, cycle I and cycle II in every aspect of beginning reading: decoding and recording for total 20 indicators in group of children 5-6 years old at Dandelion Daycare Plus Depok.

- Teachers do the beginning reading ability by using mini garden as the learning strategy with the steps covering: (1) providing the literacy environment in daycare with symbols and sign, (2) children add the vocabulary with different planting information and procedures in mini garden, and (3) managing varied learning environment.

\section{REFERENCES}

[1] Rathbun.Amy, Relationship between Full day Kindergarten Instructional Environment and Reading Achievement. Washingthon DC: American Institute for Research, 2010.

[2] Tarigan. Guntur Henry, Membaca Sebagai Suatu Keterampilan Berbahasa, Bandung: Angkasa, 2008. 
[3] Hill,. Susan, "Early Reading and Practice-inspired research,"Magill, University of South Australia, Early Child Development and Care, 2017, vol 187:3-4.

[4] D.K Dickinson, Anastasopoulos. I, McCabe, A, "The comprehensive Languange Approach to Early Literacy : The Interrelationships among vocabulary, Phonlogical Sensitivity, and Print Knowledge among Preschool-Aged Children", Vanderbilt University: Journal of Educational Psychology, September 2003, vol 95, pp 465-481.

[5] Pinto. Ana Isabel, Pessanha. Manuela and Aguia. Cecilia, "Effects of home environment and center-based child care quality on children's language, communication, and literacy outcomes", Portugal: Early Childhood Research Quarterly, 2103, vol 28,pp 94-101.

[6] Sonowat. Reeta, Maria Francis. Jasmine, Language Development for Preschool Children. Mumbai: Muti-tech Publishing co, 2007.

[7] Lynch. Jacqueline, "Preschool Teacher's belief about Children's print Literacy Development". Toronto, Canada : Faculty of Education, York Univerisity, Early Years An International Research Journal, 2009, vol 29 , issue 2, pp 191-203.

[8] Brewer. Jo Ann. Early Childhood Education Preschool through Primary Grades. Boston: Pearson Education, 2007

[9] Hofslundsengen. Hilde, Magnusson. Marin, Syensson.Ann Katrin, Jusslin. Sofia, Mellgren. Elisabeth, Hagtvet.Bente.E and Ylikallio. Ria Heilä, "The Literacy Environment of Preschool Classrooms In the Three Nordic Countries: Challenges In A Multilingual and Digital Society".
Early Child Development and Care, Norway :Westren Norway University, 2018.

[10] Holttum. R.E, Enoch. Ivan, Gardening in the Tropics: The Definitive Guide for Gardeners. London : Marshall Cavendish Children's Books, 2010.

[11] Kilicgun. Muge Yurtsever, "The Games 3-6 aged children's wish to play in the school garden", Erzincan, Turkey: Department of Early Childhood Education, October 2014, vol 152, pp 233-240,

[12] Bucher, Katie, "Opening Garden Gates : Teacher Making Meaning of School Gardens In Havana and Philadelphia", Indiana: Indiana University, April 2017, vol 63,pp 12-21.

[13] Okayama.Tsuyoshi, and Miyawaki.Kazuya, "The Smart Garden System using Augmented Reality", Ibaraki: Ibaraki University, Inashiki-Gun, IFAC Proceedings, 2013, vol 46, issue 2, pages 307-310.

[14] Almers.Ellen, Askerlund.Per \& Kjellström.Sofia, "Why forest gardening for children? Swedish forest garden educators' ideas, purposes, and experiences", Jonk€oping, Sweden : The Journal of Environment Education, April 2017,vol. 49 issue 3, pp 242-259.

[15] Kemmis and Taggart, "The Action Research Planner", Australia: Deakin University, SLD, 1990. 